\title{
FACILITIES FOR ANIMAL FEED PRODUCTION AS SALMONELLA RESERVOIRS AND SOURCES OF FINAL PRODUCTS CONTAMINATION
}

\author{
Bojana Prunić1*, Dubravka Milanov ${ }^{1}$, Aleksandar \\ Mašić ${ }^{2}$, Sandra Jakšić ${ }^{1}$, Ksenija Nešić ${ }^{3}$ \\ ${ }^{1}$ Scientific Veterinary Institute „Novi Sad”, Novi Sad \\ ${ }^{2}$ Faculty of Ecological Agriculture, Educons University, Sremska Kamenica \\ ${ }^{3}$ Scientific Veterinary Institute Serbia, Beograd
}

\section{Abstract}

Animal feed is the first link in the cycle "farm to fork" and the first potential place for entry of alimentary pathogens into the food chain. Special attention is given to bacteria from the genus Salmonella due to significant health and economic concerns related to salmonellosis in both human and veterinary medicine worldwide. Animal feed can become infected with salmonella through contaminated raw materials of animal and plant origin, but contamination of final products can occur during processing and postprocessing in facilities for their production. The life cycle of Salmonella species occurs partly in higher organisms, and partly in the living environment. Their ubiquitous distribution and survival in the environment (outside the host organism) in soil, water, on plant matter as well as on various artificial materials is made possible by the formation of multicellular communities known as the biofilm. Biofilms are multicellular bacterial formations that are irreversibly adhered to surfaces, incorporated into the extracellular substance produced by themselves and which exhibit significantly different properties (biofilm phenotype) in relation to those that grow in the suspension (planktonic phenotype). One of the most important characteristics of biofilm phenotype is the increased bacterial resistance to various stress factors in the environment, including chemical and thermal treatments, and the mechanical cleaning and sanitation. By creating the biofilm, salmonella enables its survival and persistence for months or years on equipment and working surfaces in animal feed production facilities. Due to the ubiquitous distribution of Salmonella species in nature, and therefore on plant matter

${ }^{1 *}$ Corresponding author: bojana@niv.ns.ac.rs 
as the primary raw material for the production of animal feed, it is unlikely that Salmonella could be eradicated from the food chain. Control measures should be directed to the prevention of contamination.

Key words: animal feed, Salmonella, biofilm, persistence, control

\title{
OBJEKTI ZA PROIZVODNJU HRANE ZA ŽIVOTINJE KAO REZERVOARI SALMONELLLA I IZVORI KONTAMINACIJA FINALNIH PROIZVODA
}

\author{
Bojana Prunić ${ }^{1 *}$, Dubravka Milanov ${ }^{1}$, Aleksandar \\ Mašić ${ }^{2}$, Sandra Jakšić ${ }^{1}$, Ksenija Nešić ${ }^{3}$ \\ ${ }^{1}$ Naučni institut za veterinarstvo „Novi Sad”, Novi Sad \\ ${ }^{2}$ Fakultet Ekološke poljoprivrede, Univerzitet Educons, Novi Sad \\ ${ }^{3}$ Naučni institut za veterinarstvo Srbije, Beograd
}

\section{Kratak sadržaj}

Hrana za životinje je prva karika u ciklusu "od njive do trpeze" i prvo potencijalno mesto ulaska alimentarnih patogena u lanac ishrane. Posebna pažnja pridaje se bakterijama iz roda Salmonella, zbog velikog zdravstvenog i ekonomskog značaja koji salmoneloze imaju u humanoj i veterinarskoj medicini u zemljama širom sveta. U hranu za životinje salmonele mogu dospeti kontaminiranim sirovinama animalnog i biljnog porekla, ali se kontaminacija finalnih proizvoda može desiti i tokom prerade i postprocesno, u objektima za njihovu proizvodnju. Životni ciklus Salmonella vrsta odigrava se delom u višim organizmima, a delom u životnom okruženju. Njihova ubikvitarna rasprostranjenost i preživljavanje u okruženju (izvan organizma domaćina), u zemljištu, vodi, na biljnoj materiji, kao i na različitim veštačkim materijalima, omogućeno je formiranjem višećelijskih zajednica poznatih pod nazivom. Biofilmovi su višećelijske zajednice bakterija koje su ireverzibilno vezane za površine, uklopljene u vanćelijsku supstancu koju same produkuju i koje pokazuju radikalno drugačije osobine (biofilm fenotip) u odnosu na one koje pokazuju dok rastu u suspenziji (planktonski fenotip). Jedna od najvažnijih karakteristika biofilm fenotipa je povećana otpornost bakterija na različite stresogene faktore okruženja, uključujući hemijske i termičke tretmane, kao i procedure mehaničkog čišćenja i sani- 
tacije. Rastom u biofilmovima salmonele opstaju mesecima, pa čak i godinama na opremi i radnim površinama u objektima za proizvodnju hrane za životinje. S obzirom na ubikvitarnu rasprostranjenost Salmonella vrsta u prirodi, a time i biljnoj materiji kao osnovnoj sirovini za proizvodnju hrane za životinje, malo je verovatno da će Salmonella biti iskorenjena iz lanca ishrane. Mere kontrole treba usmeriti na prevenciju kontaminacije.

Ključne reči: hrana za životinje, Salmonella, biofilm, perzistencija, kontrola

\section{INTRODUCTION}

Bacteria belonging to the genus Salmonella are the causative agents responsible for one of the most important zoonoses and food borne transmissible infections in humans. Food producing animals (poultry, pigs, cattle) are considered reservoirs for many pathogens which can be transmitted by food, including Campylobacter species and non-Typhi serotypes of Salmonella enterica (Crump et al., 2002). The concern about animal feed safety was further raised with the appearance of variants of Creutzfeldt-Jakob disease in humans in the United Kingdom, associated with the feeding cattle with meat and bone meal (Brown et al., 2001). Contamination of animal feed with non-Typhi serotypes of S. enterica can contribute to the burden of human salmonellosis (Crump et al., 2002). Retrospective epidemiological analysis to determine the source of infection includes difficult and demanding processes; however, there is an increasing number of reports on the appearance of salmonellosis in humans where animal feed have been identified as the primary causative source (Pennington et al., 1968; Crump et al., 2002).

Salmonella can reach into the animal feed by multiple ways and during all production stages (Habimana et al., 2010; Berge and Wierup, 2012). Salmonella species successfully persist in soil, aquatic systems, plant matter, equipment and surfaces of artificial materials with which food comes into contact during processing and production. Formation of multicellular communities known as biofilm, represents normal part of the life cycle in most Salmonella species (Jonas et al., 2007; Steenackers et al., 2012). These strains could be a source of contamination of raw materials and final products in food and feedstock production facilities for months or years. 


\section{BOTANICAL RAW MATERIALS AS SOURCE OF SALMONELLA}

In addition to food of animal origin that are traditionally considered the main source of salmonella for humans, recent epidemiological studies identified food of plant origin as additional source of contamination with Salmonella (Lapidot et al., 2006; Steenackers et al., 2012; Cevallos-Cevallos et al., 2012). Due to the extremely large adaptive ability to diverse environmental conditions and ubiquitous distribution in the living environment, Salmonella species are able to survive on plant matter by internalizing in stems, cracks and fenced areas, or by forming biofilms that are their natural form on the surface of the plants (Srey et al., 2013). Salmonella spp. can reach plants through contaminated irrigation water or using raw fertilizers (Barak and Liang, 2008; Steenackers et al., 2012). Salmonella can be isolated from agricultural crops and soils six months or more after contamination (Teplitski et al., 2009; Barak et al., 2009). Epidemiological studies confirmed that a number of salmonella-related epidemics in humans are associated with the consumption of contaminated plants (seeds, spawns, leaves, root etc.) emphasizing plants as an important vector for transmission of Salmonella spp. (Heaton and Jones, 2008; Berger et al., 2010; Steenackers et al., 2012). Using microscopic techniques for in-situ visualization, it has been found that salmonella has the ability not only to contaminate but also to colonize and actively invade plants (Lapidot and Yaron, 2009; Barak et al., 2009; Kroupitski et al., 2009; Patel and Sharma, 2010). It was experimentally confirmed that strains of S. Newport and S. Enteritidis actively colonize the surface of the alfalfa and form a biofilm (Barak et al., 2009).

\section{SALMONELLA BIOFILM IN ANIMAL FEED PRODUCTION FACILITIES}

Salmonella reach animal feed production facilities through contaminated raw materials (Nesse et al., 2003) and utilize similar survival mechanism on inert surfaces, artificial materials, and in the natural environment. Salmonella creates biofilm on the equipment and working surfaces, with which contaminated raw materials come into contact in food production plants. This way, the sources of process and post-process product contamination are established (Nesse et al., 2003; Vestby et al., 2009a). Salmonella spp. could be found in the rooms for raw material receiving, milling facilities and mixing mills, packing machines, conveyor belts, floors, drainage channels (cross-contamination with dust and aerosols), transport vehicles, as well as storage facilities for finished products (Nesse et al., 2003; Vestby et al., 2009a; Habimana et al., 2010; Steenackers et al., 2012; Giaouris et al., 2012). 
Biofilm formation is a strategy that Salmonella spp. utilize to persist on various types of materials: stainless steel, plastic, rubber, glass, wood, marble, and granite that are commonly used in animal feed production facilities (Stepanović et al., 2004; Giaouris et al., 2005; Møretrø et al., 2009; Rodrigues et al., 2011; Carrasco et al., 2012; Steenackers et al., 2012; Giaouris et al., 2012). Contaminated equipment and surfaces can be the source of contamination of final products for months and even years, despite the regular implementation of rigorous cleaning and disinfection measures (Nesse et al., 2003; Vestby et al., 2009a; Møretrø et al., 2009).

In industrial plants, the development of bacterial biofilms is commonly related to improper cleaning and disinfection of the equipment (O'Leary et al., 2013; Srey et al., 2013). Bacteria organized in biofilm demonstrate greater levels of resistance to various stress-related factors such as drying and disinfection (Møretrø et al., 2009; Aviles et al., 2013). In general, implementation of effective programs for cleaning and remediation could prevent the generation of new biofilms; however, there are no effective strategies for eradicating already formed biofilms.

Frequent findings of certain Salmonella enterica serotypes such as S. Agona, S. Montevideo, S. Senftenberg, S. Mbandaka, S. Tennessee, S. Typhimurium, S. Livingstone in animal feed facilities are explained by their ability to persist in the form of biofilm on artificial surfaces (Vestby et al., 2009a; Papadopoulou et al., 2009; Habimana et al., 2010). The development of molecular techniques (pulsed-field gel electrophoresis- (PFGE) and plasmid profile typing) provided evidence that the clones of various Salmonella sero-species (the so-called "house strain") can persist for months or years in food production plants (Nesse et al., 2003; Vestby et al., 2009a; Vestby et al., 2009b; Møretrø et al., 2009; Habimana et al., 2010; Prunić et al., 2016).

\section{SUBSEQUENT CONTAMINATION OF ANIMAL FEED WITH SALMONELLA SPP.}

Potential sources for subsequent contamination of animal feed with Salmonella species are rodents, birds and insects that can transmit or excrete bacteria through feces, urine and feathers. In some production areas, abiotic factors such as condensation caused by temperature variations can provide sufficient moisture levels required to support growth and formation of salmonella or other bacterial related biofilms (Bogvist et al., 2003; Mynt et al., 2007; Habimana et al., 2010; Jones, 2011; Sokolović et al., 2011). Dust is also considered a potential source of contamination in mills for mixing and splitting, worms and 
storage facilities (Jones, 2011). Also, leakage, moisture condensation, nutrient retention in individual devices and conveyors, insufficient warming in thermal processes create favorable conditions for the re-development of microorganisms (Habimana et al., 2010; Jones, 2011).

\section{CONTROL AND ERADICATION MEASURES FOR SALMONELLA SPP. IN THE PROCESS OF ANIMAL FEED PRODUCTION}

Given the broad presence of Salmonella species, it is unlikely that Salmonella will be eradicated from the food chain (Humphrey et al., 2004) but implementation of control measures should reduce the possibility of contamination.

Control measures for Salmonella spp. during the process of animal feed production can be classified into three categories: a) prevention of entry of Salmonella into production facilities; b) prevention of their replication within facilities c) methods for eradicating the already present microorganisms.

Prevention of contamination measures in production facilities involves control of dust, staff movement, use of the equipment, eradication of the rodents, and prevention of access to wild birds, and sanitation of transport vehicles. Reduction or control of Salmonella spp replication in food production facilities involves the detection of favorable niches for their growth and survival, as well as the elimination of the conditions leading to their growth. Elimination of Salmonella spp. refers to thermal treatment (pelleting, extrusion) or chemical treatment (Habimana et al., 2010; Jones, 2011; Berge et al., 2012).

The replication of microorganisms in animal feed is affected by a number of environmental factors such as moisture content or water activity in the food, relative humidity, $\mathrm{pH}$ value, oxidation reduction potential, percentage of fat (plant matter), presence of salt and carbohydrates, amount of nutrients, and temperature (Bogvist et al., 2003; Sokolović et al., 2011). In the process of food production control, dust has been identified as a critical point in contamination and re-contamination and control measures for dust levels in production facilities are established (Butcher and Miles, 1995). Dust is mostly present in raw materials, and consequently in reception areas and storage facilities. Furthermore, dust is largely present in milling and mixing mills, rollers, worm conveyors, transport belts, which is why it represents the challenging task for the control of Salmonella in all animal feed production facilities (Jones, 2011).

Animal feed often contains certain percentage of moisture, which can be increased by absorption from environment during long-term storage, condensation or absorption from humid air (Bogvist et al., 2003). Increased moisture content in food can also occur due to roof damages and leaking. 
The major problem in controlling Salmonella in animal feed production facilities is the presence of rodents and wild birds. Rodents are a significant source of food contamination for salmonella (Morita et al., 2006), and according to multiple reports, they are estimated as sources of contamination in $47 \%$ of reported cases (Meerburg et al., 2007). Salmonella spp. can be permanent inhabitant of the digestive tract in wild birds and could be excreted into the environment. Wild birds get in contact with Salmonella through feeding at landfills, near and in sewage outlets, through feces and corpses, as well as animal feeds close to the food production facilities (Benskin et al., 2009; Jones, 2011). Measures of pest control and control of the access to wild birds must therefore be an integral part of Salmonella control program in animal feed production facilities.

Transportation vehicles are also identified as a potential source of contamination of raw materials and feed ingredients due to difficulties related to thorough cleaning and disinfection between deliveries, as these processes are time consuming an economically not-feasible (Whyte et al., 2003). Staff employed in animal feed facilities could also contribute to the creation of favorable conditions for the growth of microorganisms due to poor training for handling the equipment and improper implementation of hygiene measures in accordance with the principles of good manufacturing practice.

Pelleting and extrusion processes are considered successful in the elimination of microorganisms from the animal feed (Jones, 2011). The pelleting process encompasses three stages: mixing steam with food, exposing food to high pressure (pellet formation) and removing heat and moisture by cooling. The pelleting process reduces number of Salmonella spp at a range from 50\% to $93 \%$. (Jones et al., 1991; Veldman et al., 1995; Jones, 2011). The pelleting process involves the use of a large amount of steam for the destruction of microorganisms, which results in an increase in pellet moisture. High temperatures during the pelleting process reduce the number of micro-organisms, but their numbers often increase later again. The reason for that is the potential contamination in the pellet cooling phase through contaminated dust and condensation due to variations in temperature, which ensures the humidity of the microorganism's life cycle (FAO, 2010; Sokolović et al., 2011).

However, heat treatment of animal feed has shown insufficient efficacy in controlling salmonella (Habimana et al., 2010). Studies have shown that Salmonella spp. survive temperature and humidity fluctuations in the feed production facilities by entering viable but nonculturable (VBNC) state (Møretrø et al., 2009; Habimana et al., 2010; Habimana et al., 2014). The impact of stress factors such as temperature changes, $\mathrm{pH}$ values, osmolarity, availability of nutrients, etc., induce 
the transition of bacteria into a life-long, but not culturally (VBNC) condition. Such VBNC bacteria are metabolically active but do not replicate.

In addition to heat treatment, in order to eliminate Salmonella from raw materials and ready-to-feed foods, animal feed producers use organic acids, mechanical, physical and chemical methods and various treatments for sanitation (Sauli et al., 2005, Papadopoulou et al., 2009; Berge et al., 2012).

Although thermal treatment of food is generally considered to be the most effective method for eliminating pathogens, in some circumstances it is not sufficient and other options are applied. In such cases, the application of chemical methods may offer alternative protection methods. Treatment of food ingredients and mixtures of nutrients with organic acids or formaldehyde at permitted concentrations may be effective in reducing amounts of salmonella spp. and other microorganisms. In order to reduce or eliminate Salmonella spp. in animal feed, organic acids (ant, propionic, vinegar and butter) and formaldehyde are commonly used (Berge et al., 2012). Organic acids are added in an amount of $0.2-2 \%$ to inhibit the growth of Salmonella spp. (Vahl, 1995; Jones, 2011). Acid efficiency is variable and depends on a number of factors such as acid type, chemical form of acid (free acid or acid s), percentage of moisture in food (EFSA, 2008; Jones, 2011). Adding organic acids to animal feed changes its $\mathrm{pH}$ value ( $\mathrm{pH} 4.5$ and lower) and creates unfavorable conditions for the growth and survival of Salmonella (Dahiya et al., 2006). Application of chemical treatments in order to reduce or eliminate pathogens has its own shortcomings in terms of price, duration (few days), undesirable effect of acid on metal surfaces of equipment (corrosion), change in food taste and reduction in vitamin concentrations (EFSA, 2008; Jones, 2011). The use of formaldehyde is avoided due to evaporation and its toxicity to humans. Other compounds such as chlorine, peroxides, or ammonium compounds are also used, which also have a residual effect and cause changes in the sensory properties of the final products.

In addition to mechanical cleaning, physical sanitation treatments involve the use of ultrasound at different frequencies, magnetic and electric fields and various types of radiation. The use of ultraviolet light (UV) is a good method for disinfection of air and surfaces, including packaging material. Treatment by UV light is a simple, efficient and economical way of sanitation as compared to other technologies. It is also a cold, dry process that does not create chemical residues. Physical treatments, although they provide good results, are often not applicable and unacceptable due to economic reasons (high costs and technical equipment).

In order to avoid the detrimental effects of chemical treatments and expensive physical processes, more efforts were put towards discovering more 
effective biological solutions to reduce or eliminate Salmonella spp. and other pathogenic microorganisms in animal feed. Biological approaches include the use of antimicrobial compounds of plant origin such as extracts of essential oils and various spices, antimicrobial compounds produced by microorganisms as well as enzymes (Simões et al., 2010).

Scandinavian countries (Denmark, Norway and Sweden) have developed integrated Hazard Analysis and Critical Control Points (HACCP) for each step in the food chain, ensuring food safety in order to improve food quality, increase safety and accountability (Lević et al., 2009; Sokolović et al., 2011). This multiple control program has shown great success in eliminating Salmonella spp. from facilities for production of animal feed and products of animal origin, which resulted in a decrease in the incidence of salmonella in humans at an annual level (Crump et al., 2002).

Our country does not have developed and integrated monitoring system that includes facilities for production of animal feed, products of animal origin intended for human consumption, and the occurrence of alimentary infections in humans. In Serbia, the provisions of Article 82 of the Veterinary Law imposed from January 1, 2009 (Official Gazette of the Republic of Serbia 91/05) refer to the implementation of the "HACCP" and are based on hazard analysis and critical Control points in production.

\section{ACKNOWLEDGMENTS}

The research is supported by a grant from the Ministry of Education Science and Technological Development, Republic of Serbia, Project number TR 31084.

\section{REFERENCES}

1. Aviles B., Klotz C., Eifert J., Williams R., Ponder M.: Biofilms promote survival and virulence of Salmonella enterica sv. Tennessee during prolonged dry storage and after passage through an in vitro digestion system. International Journal of Food Microbiology, 162, 252-259, 2013.

2. Barak J.D., Gorski L., Liang A.S., Narm K.E.: Previously uncharacterized Salmonella enterica genes required for swarming play a role in seedling colonization. Microbiology, 155, 11, 3701-3709, 2009.

3. Barak J.D., Liang A.S.: Role of soil, crop debris, and a plant pathogen in Salmonella enterica contamination of tomato plants. PLoS ONE, 3, 2, e1657, 2008. 
4. Benskin C.M.H., Wilson K., Jones K., Hartley I.R.: Bacterial pathogens in wild birds: A review of the frequency and effects of infection. Biological Reviews of the Cambridge Philosophical Society, 84, 349-373, 2009.

5. Berge A. C., Wierup M.: Nutritional strategies to combat Salmonella in mono-gastric food animal production. Animal, 6, 4, 557-564, 2012.

6. Berger, C.N., Sodha, S.V., Shaw, R.K., Griffin, P.M., Pink, D., Hand, P., Frankel, G.: Fresh fruit and vegetables as vehicles for the transmission of human pathogens. Environmental Microbiology, 12, 9, 2385-2397, 2010.

7. Bogvist S, Hansson I., Bjerselius U.N., Hamilton C., Wahlström H., Noll B., Tysen E., Engvall A.: Salmonella isolated from animals and feed production in Sweden between 1993 and 1997. Acta Veterinaria Scandinavica, 44,181, 2003.

8. Brown P., Will R.G., Bradley R., Asher D.M., Detwiler L.: Bovine spongiform encephalopathy and variant Creutzfeldt-Jacob disease: background, evolution, and current concerns. Emerging Infectious Diseases, 7, 6-16, 2001.

9. Butcher, G. D. and Miles, R. D. 1995. Minimizing microbial contamination in feed mills producing poultry feed. Coop. Ext. Serv. Publ. No. VM93. University of Florida, Gainesville.

10. Carrasco E., Morales-Rueda A., García-Gimeno R.M.: Cross-contamination and recontamination by Salmonella in foods: A review. Food Research International 45, 545-556, 2012.

11. Cevallos-Cevallos J.M., Gu G., Danyluk M.D., van Bruggen A.H.C.: Adhesion and splash dispersal of Salmonella enterica Typhimurium on tomato leaflets: Effects of rdar morphotype and trichome density. International Journal of Food Microbiology 160, 58-64, 2012.

12. Crump J.A., Griffin P.M., Angulo FJ.: Bacterial contamination of animal feed and its relationship to human illness. Clinical Infectious Diseases, 35, 859-865, 2002.

13. Dahiya J.P., Wilkie D.C., Van Kessel A.G., Drew M.D.: Potential strategies for controlling necrotic enteritis in broiler chickens in post-antibiotic era. Animal Feed Science and Technology, 129, 60-88, 2006.

14. EFSA: European Food Safety Authority. Microbiological risk assessment in feedingstuffs for food-producing animals. Scientific Opinion of the $\mathrm{Pa}$ nel on Biological Hazards. The EFSA Journal, 720, 1-84, 2008.

15. FAO: Manual of Good Practices for the Feed Industry. Link: http://www. fao.org/docrep/012/i1379e/i1379e00.pdf, (2010).

16. Giaouris E., Chorianopoulos N., Skandamis P.N., Nychas G.J.: Attachment and biofilm formation by Salmonella in food processing environments, in: Barakat, S.M.M. (Ed.), Salmonella - A dangerous foodborne pathogen. InTech, Rijeka, Croatia, 57-180, 2012. 
17. Giaouris E.D., Chorianopoulos N., Nychas G.J.E.: Effect of Temperature, $\mathrm{pH}$, and Water Activity on Biofilm Formation by Salmonella enterica Enteritidis PT4 on Stainless Steel Surfaces as Indicated by the Bead Vortexing Method and Conductance Measurements. Journal of Food Protection, 68, 10, 2149-2154, 2005.

18. Habimana O., Møretrø T., Langsrud S., Vestby L.K., Nesse L.L., Heir E.: Micro ecosystems from feed industry surfaces: a survival and biofilm study of Salmonella versus host resident flora strains. BMC Veterinary Research, 6-48, 2010.

19. Habimana O., Nesse L.L., Møretrø T., Berg K., Heir E., Vestby L.K., Langsrud S.: The persistence of Salmonella following desiccation under feed processing environmental conditions: a subject of relevance. Letters in Applied Microbiology, 59, 5, 464-470, 2014.

20. Heaton J.C., Jones K.: Microbial contamination of fruit and vegetables and the behaviour of enteropathogens in the phyllosphere: A review. Journal of Applied Microbiology, 104, 3, 613-626, 2008.

21. Humphrey, T.: Salmonella, stress responses and food safety. Nature Reviews Microbiology, 2, 504-509, 2004.

22. Jonas, K., Tomenius, H., Kader, A., Normark, S., Römling, U., Belova, L. M.: Roles of curli, cellulose and BapA in Salmonella biofilm morphology studied by atomic force microscopy. BMC Microbiology, 7, 70, 2007.

23. Jones F.T., Axtell R.C., Rives D.V., Scheideler S.E., Tarver F.R., Walker R.L., Wineland M. J.: A survey of Salmonella contamination in modern broiler production. Journal of Food Protection 54, 502-507, 1991.

24. Jones F.T.: A review of practical Salmonella control measures in animal feed. Journal of Applied Poultry Research, 20, 102-113, 2011.

25. Kroupitski Y., Golberg D., Belausov E., Pinto R., Swartzberg D., Granot D., Sela S.: Intenalization of Salmonella enterica in leaves is induced by light and involves chemotaxis and penetration through open stomata. Applied and Environmental Microbiology, 75, 19, 6076-6086, 2009.

26. Lapidot A., Römling U., Yaron S.: Biofilm formation and the survival of Salmonella Typhimurium on parsley. International Journal of Food Microbiology, 109, 229-233, 2006.

27. Lapidot A., Yaron S.: Transfer of Salmonella enterica serovar Typhimurium from contaminated irrigation water to parsley is dependent on curli and cellulose, the biofilm matrix components. Journal of Food Protection, 72, 3, 618-623, 2009.

28. Lević J., Sredanović S.: Prilagođavanje i sprovođenje zakonodavstva EU na nacionalnom nivou. TAIEX workshop, Novi Sad, AGR 32323, 2009. 
29. Meerburg B.G., Kijlstra A.: Role of rodents in transmission of Salmonella and Campylobacter. Journal of the Science of Food and Agriculture, 87, 2774-2781, 2007.

30. Møretrø T., Vestby L.K., Nesse L.L., Storheim S.E., Kotlarz K., Langsrud S.: Evaluation of efficacy of disinfectants against Salmonella from the feed industry. Journal of Applied Microbiology, 106, 3, 1005-1012, 2009.

31. Morita T., Kitazawa H., Iida T., Kamata S.: Prevention of Salmonella cross-contamination in an oilmeal manufacturing plant. Journal of Applied Microbiology, 101, 464-473, 2006.

32. Mynt S.M., Johnson Y. J., Paige J.C., Bautista D.A.: A cross- sectional study of bacterial contamination in plant-protein feed from feed stores in Northern Virginia and Maryland. Animal Feed Science and Technology, 133, 137-148, 2007.

33. Nesse L.L., Nordby K., Heir E., Bergsjoe B., Vardund T., Nygaard H.: Molecular analyses of Salmonella entericaisolates from fish feed factories and fish feed ingredients. Applied and Environmental Microbiology, 69, 10751081, 2003.

34. O'Leary D., McCabe E.M., McCusker M.P., Martins M., Fanning S., Duffy G.: Microbiological study of biofilm formation in isolates of Salmonella enterica Typhimurium DT104 and DT104b cultured from the modern pork chain. International Journal of Food Microbiology, 161, 36-43, 2013.

35. Papadopoulou C., Carrique-Mas J.J., Davies R.H., Sayers A.R.: Retrospective analysis of Salmonella isolates recovered from animal feed in Great Britain. Veterinary Record, 165, 681-688, 2009.

36. Patel J., Sharma M.: Differences in attachment of Salmonella enterica serovars to cabbage and lettuce leaves. International Journal of Food Microbio$\log y$, 139, 41-47, 2010.

37. Pennington J.H., Brooksbank N.H., Pool P.M., Seymour F.: Salmonella Virchow in a chicken-packing station and associated rearing units. $\mathrm{Br}$ Med $\mathrm{J}$ 4, 804-806, 1968.

38. Prunić B., Milanov D., Velhner M., Pajić M., Pavloviæ L., Mišić D.: Clonal persistence of Salmonella enterica serovars Montevideo, Tennessee and Infantis in feed factories. Journal of Infection in Developing Countries, 10, 662-666, 2016.

39. Rodrigues D., Teixeira P., Oliveira R., Azeredo J.: Salmonella enterica Enteritidis biofilm formation and viability on regular and triclosan-impregnated bench cover materials. Journal of Food Protection, 74, 1, 32-37, 2011.

40. Sauli I., Danuser J., Geeraerd A.H., Van Impe J.F., Rüfenacht J., BissigChoisat B., Wenk C., Stärk K.D.C.: Estimating the probability and level 
of contamination with Salmonella of feed for finishing pigs produced in Switzerland-the impact of the production pathway. International Journal of Food Microbiology, 100, 289-310, 2005.

41. Simões M., Simões L.C., Vieira M.J.: A review of current and emergent biofilm control strategies. LWT - Food Science and Technology, 43, 4, 573 $583,2010$.

42. Sokolović M., Ruk I.: Sigurnost hrane za životinje i primjena HACCP-a u tvornicama hrane za životinje. Stočarstvo, 65, 3, 219-235, 2011.

43. Srey S., Jahid I.K., Ha S.D.: Biofilm formation in food industries: A food safety concern. Food Control, 31, 2, 572-585, 2013.

44. Steenackers H., Hermans K., Vanderleyden J., De Keersmaecker S.C.J.: Salmonella biofilms: An overview on occurrence, structure, regulation and eradication. Food Research International, 45, 502-531, 2012.

45. Stepanović S., Cirković I., Ranin L., Svabić-Vlahović M.: Biofilm formation by Salmonella spp. and Listeria monocytogenes on plastic surface. Letters in Applied Microbiology, 38, 5, 428-432, 2004.

46. Teplitski M., Barak J. D., Schneider K. R.: Human enteric pathogens in produce: Un-answered ecological questions with direct implications for food safety. Current Opinion in Biotechnology, 20, 2, 166-171, 2009.

47. Vahl I. J.: Breaking the Salmonella chain at the feed mill. Feed Mix, 3, 1417, 1995.

48. Veldman A., Vahl H.A., Borggreve G.J., Fuller D.C.: A survey of the incidence of Salmonella species and Enterobacteriaceae in poultry feeds and feed components. Veterinary Record, 136, 169-172, 1995.

49. Vestby L., Moretro T., Langsrud S., Heir E., Nesse L.L.: Biofilm forming abilities of Salmonella are correlated with persistence in fish meal- and feed factories. BMC veterinary research, 5, 20-25, 2009a.

50. Vestby L.K., Moretro T., Ballance S., Langsrud S., Nesse L.L.: Survival potential of wild type cellulose deficient Salmonella from the feed industry. BMC Veterinary Research, 5, 43, $2009 \mathrm{~b}$.

51. Whyte P., McGill K., Collins J.D.: A survey of the prevalence of Salmonella and other enteric pathogens in a commercial poultry feed mill. Journal of Food Safety, 23, 13-24, 2003.

Primljeno: 25.07.2017.

Odobreno: 11.09.2016. 
